Peter Bennett, Mr. W. Bond, Mr. O. F. Brown, Dr. W. T. K. Braunholtz, Dr. P. Dunsheath, Mr. T. A. Fairclough, Dr. W. H. Glover, Dr. W. T. Griffiths, Mr. A. L. Hetherington, Lord Melchett, Mr. R. O'F. Oakley, Dr. C. C. Paterson, Sir Robert Pickard, Mr. R. K. Sanders, Dr. R. E. Slade, Sir Frank Smith, Mr. S. K. Thornley, Mr. B. J. A. Bard (secretary to the Committee and head of the F.B.I. Industrial Research Secretariat).

\section{International Collaboration}

THE publication as a "Penguin Special" (price 9d.) of E. R. Stettinius' 'Lend-Lease: Weapon for Victory" shortly after its original publication as a substantial work of 358 pages (New York: The Macmillan Company ; London : Macmillan and Co., Ltd.) is a real service to Anglo-American understanding. Intended originally to facilitate the understanding in the United States of the Lend-Lease Act, it should contribute equally in Britain to the same end. This is important, because, if the now lend-lease agreement with the United States announced in November by the Prime Minister is to be fully understood, it must be remembered that the Lend-Lease Act is for the defence of the United States, and is strictly limited to what is necessary for the effective prosecution of the War by the United States and its Allies. The picture which Mr. Stettinius here paints of the way in which Lend-Lease developed and of the magnitude of the contribution which has been made to victory in Europe in this way is most impressive in its demonstration of the possibilities of collaboration between the United Nations and of the advantages which all might reap from the pooling of economic resources in facing the tasks and problems of peace. At a time when the organization of world order is receiving close attention, it is well that there should be made so widely available such an admirable account of one great experiment in international collaboration which has played a large part in bringing the war in Europe to a successful conclusion. The principle of mutual aid embodied in the Lend-Lease Act and agreements will not come to an end when the war with Japan ends : to it we must also look for the strength to build a world in which freedom and opportunity are secure for all.

\section{British Grassland Society}

AT the Fourth International Grassland Congress held in Great Britain in 1937, a group of grassland specialists met to consider the advisability of forming a society in the United Kingdom to promote the study of grassland husbandry. The outbreak of war prevented further progress with the scheme, but in November 1944 a group interested in grassland research met to discuss the foundation of a British Grassland Society, the activities of which would be field tours, discussions and the publication of a journal. The Society was formed early in 1945 and the first meeting was held at Stratford-on-Avon during June 20-22. About one hundred and fifty members attended. At the opening general meeting the following committee and officers were elected for 1945 : President, Sir R. George Stapledon; Vice-President, Dr. Wm. Davies ; Committee, J. H. Faulder, H. J. Gill, W. D. Hay, F. R. Horne, Prof. T. J. Jenkin, M. G. Jones, Prof. S. J. Watson; Secretary, Dr. R. O. Whyte; Treasurer, P. A. Linehan ; Editor, Dr. H. I. Moore. The office of the Secretary is at the Agri- culbural Research Building, Aberystwyth. It was agreed at this meeting that membership should be confined in the meantime to scientific and technical officers of Ministries, research institutes, war agricultural executive committees and similar bodies. Specialists in countries other than Great Britain can become members.

During the meeting, members visited the Grassland Improvement Station at Drayton, its former substation at Colesbourne in the Cotswolds and representative grassland areas in Leicestershire. At Drayton, herbage crops in seed production and leys of different age, history, seeds mixtures and seeding rates were inspected. An interesting feature of the work at Drayton is the increasing emphasis which is being placed on the interpretation of sward improve. ment through the animal rather than by means of botanical or chemical analyses alone; live-weight production trials accompanied the experiments. At Colesbourne there were fertilizer trials accompanying the establishment of leys and the seed production of various forage crops. Visitors were impressed at the productivity obtained from this thin Cotswold soil which only three years ago was derelict turf and dense thorn bush. Those from the north were particularly interested in the crops of sainfoin. In a tour through Leicestershire members inspected trials of cocksfoot, perennial ryegrass and other grasses conducted jointly by the Royal Agricultural Society of England and the Leicestershire War Agricultural Executive Committee at Dunton Bassett and Thorpe Langton. They saw the trial now in progress on the famous Mill Field at Medbourne to compare beef production on an old pasture (about one hundred and fifty years old) with that on a new ley in an adjacent field. Members also inspected ley farming and a grass and grain drying plant at Skeffington. Future plans of the Society will be decided shortly. There will probably be an autumn meeting at which papers will be read and a field meeting next summer in some other part of Great Britain. It is proposed to publish a journal, which will be available to members under their subscription to the Society (21s. per annum), and to others at a subscription rate to be decided.

\section{Education and Training of Aircraft Workers}

The Royal Aircraft Establishment of the Ministry of Aircraft Production has just issued an interesting and informative pamphlet on the general subject of aeronautical training. If, says the pamphlet, Great Britain is to maintain its superiority in the air, we must enlist the help of intelligent young men and young women, and give them a training in an attractive career full of possibilities. The basis of the scheme now proposed is the highly efficient technical college which has been built up as an integral part of the Establishment. The scheme set forth in the pamphlet is a system of apprenticeship, the apprentices being of three types: (1) engineering apprentices, who are trained to become aeronautical research engineers, and are drawn from boys who have -attained a high standard of secondary school education; (2) craft apprentices, who are trained to become skilled craftsmen for service in laboratories and in experimental work ; and (3) laboratory assistants, who are employed in the research laboratories, and must have obtained a school-leaving certificate with credit in science and mathematics. Details are given concerning the course of training for each of the three types of apprentice. The course in each case 
is prolonged and thorough, and it is shown that for each type there is the possibility and the promise of a successful career.

\section{What are Comets?}

Cienciae Investigación No. 2, February 1945, contains an article with the title "¿Qué son los cometas?" by Enrique Gaviola, director of the Córdoba Observatory, which gives a short account of comets from ancient times up to the present. There is nothing new in the article, but it provides a useful summary of our knowledge of these visitors, dealing with the spectrograms of the gases in the head and tail, the masses deduced by the perturbations or lack of perturbations produced by comets, changes in luminosity due to varying distances from the sun, light pressure on the smaller particles, etc. The author conjectures that the asteroids were once brilliant comets-a view which is entertained by others, but lacking in conclusive evidence. There is a very fine photograph of Halley's Comet taken at Córdoba Observatory on May 7, 1910.

\section{Recent Earthquakes}

During January 1945, ten earthquakes were registered at the seismological observatory at Toledo, Spain. The greatest of these was on January 12, when an earthquake, registering initially at $18 \mathrm{~h} .52 \mathrm{~m}$. 0 ls. G.м.T., developed an amplitude of $50 \mu$ at $19 \mathrm{~h}$. $36 \mathrm{~m}$. 13s. G.M.T. on the east-west component. The epicentral distance has been provisionally estimated at $12,830 \mathrm{~km}$. During the same month one strong distant earthquake was registered at the Dominion Observatory, Wellington, New Zealand. This was on January 28 at $07 \mathrm{~h}$. $37 \mathrm{~m}$. 18s. G.M.T. from an epicentral distance of approximately $22^{\circ}$. The shock was also registered at Christchurch, Auckland and Arapuni. In New Zealand there were twelve shocks humanly felt in the Dominion during the month. The greatest of these was on January 2 . It was felt with intensity 5 (Modified Mercalli Scale) in the North Island, south of Wairo Taupo and Wanganui. On January 1 a shock was also felt at Wairo with intensity 5 (Mod. Mer.). The United States Coast and Geodetic Survey, in co-operation with Science Service and the Jesuit Seismological Association, has determined the provisional epicentre of the earthquake of January 12 to be near lat. $34^{\circ} \mathrm{N}$, long. $139^{\circ} \mathrm{E}$., which is off the coast of Japan, to the south of Tokyo.

During February 1945, fourteen strong earthquakes were registered at the observatory at Toledo, Spain. The strongest of these occurred on February 10 and registered at Toledo at 05h. 11m. 09s. G.M.T., attaining a maximum ground amplitude at Toledo of $115 \mu$ on the north-south component at $05 \mathrm{~h} .50 \mathrm{~m}$. 35s. G.M.T. The epicentral distance is estimated at $10,440 \mathrm{~km}$. The shock of February 20 is estimated to have had its epicentre $660 \mathrm{~km}$. from Toledo. The earthquake of February 18 was recorded at Kew, as was also that of February 26. The United States Coast and Geodetic Survey, in co-operation with Science Service and the Jesuit Seismological Association, has determined the provisional epicentre of the earthquake of February 10, from instrumental reports from twenty-one observatories, to have been at lat. $41 \cdot 5^{\circ} \mathrm{N}$., long. $142^{\circ} \mathrm{E}$., which is off the coast of Japan to the east of Hakodate. The initial time was $4 \mathrm{~h} .57 \cdot 9 \mathrm{~m}$. G.M.T.

During March 1945, Mr. E. W. Pollard recorded seven earthquakes at his observatory at Binstead, Isle of Wight. Three occurred on March 18.

\section{The Film in Science}

The Scientific Film Association is holding a conference on "The Film in Science" at the Technical College, Huddersfield, during August 31--September 2. The opening address will be given by Mr. Arthur Elton, president of the Association, and there will be sessions on the film in education, industry and medicine, and as an instrument of research. Dr. W. T. Astbury will give a lecture on the X-ray examination of proteins. There will be a display of visual aid equipment. Registration forms to attend the conference, and further particulars, can be obtained from the secretary of the Association, e/o Royal Photographic Society, 16 Princes Gate, London, S.W.7.

\section{United Nations Educational Conference in London}

A CONFERENCE is to be held in London on November I next to consider the establishment of a United Nations Educational and Cultural Organization. The Conference of Allied Ministers under the chairmanship of Mr. Richard Law, Minister of Education, at a meeting in London on July 12, unanimously agreed that the British Government be asked to invite on its behalf the Governments of all the United Nations to send delegates to this conference. A working committee will be set up in London to make preparations for the conference and to assemble and collate opinions and proposals as to the scope and methods of operation of the organization. Draft proposals for the constitution of the organization, prepared by the Conference of Allied Ministers, will be issued shortly and will form the basis of discussion at the forthcoming conference.

\section{Announcements}

Dr. Arexander S. Wrener, of New York University, has been awarded the Alvarenga Prize for 1945 of the College of Physicians of Philadelphia, "in recognition of his important work upon the various types of Rh factors and on their genetic transmission". Dr. Wiener will give the Alvarenga Lecture before the College of Physicians of Philadelphia and the Philadelphia County Medical Society on October 3, 1945, on " $R h$ Blood Factors in Clinical Medicine". This Prize was established by the will of Pedro Francisco daCosta Alvarenga of Lisbon, Portugal, an associate fellow of the College of Physicians of Philadelphia, "to be awarded annually by the College of Physicians on each anniversary of the death of the testator, July 14, 1883". The College usually makes this award for outstanding published work, and invites the recipient to deliver an Alvarenga Lecture before the College.

THe Council of the University of Sheffield has made the following appointments: Dr. H. Motz to be lecturer in engineering physics; Dr. James White to be lecturer in refractory materials in the Department of Metallurgy. Dr. C. Gray Imrie, lecturer in physiology, and Mr. J. MacA. Croll, lecturer in bacteriology, have resigned. Mr. C. H. Hainsworth, lecturer in electrical engineering, and Dr. W. J. Rees, lecturer in refractories, are retiring under the age limit. 'The Yorkshire Mine Workers' Association is to provide two scholarships in 1946, each of an annual value of $£ 180$, open to members of the Association and tenable for a full-time degree course in mining at the University. 